\title{
The Influence on Public English Teaching in Higher Vocational Colleges from Big Data and the Present Teaching Situation
}

\author{
Chunlin Liu \\ Jiangxi Technical College of Manufacturing 330095, China
}

Keywords: Internet big data; Higher Vocational colleges; Public English; development situation; change and influence

\begin{abstract}
The rapid development of Internet technology has brought a great influence to people's life. In the background of Internet big data, the traditional English teaching mode has also been greatly reformed. This paper is to interpret the present development situation of Public English Teaching in Higher Vocational colleges, and the change and influence of Internet big data on it in the background of big data, and affirms that the big data has played a positive role in the development of English teaching.
\end{abstract}

In recent years, with the rapid development of interconnection technology and market economy, the development of higher vocational education has received a great attention. The demand for higher vocational talents is also growing rapidly, even in short supply. Different from the ordinary full-time education, the purpose of higher vocational students is to match future career development with the knowledge acquired, which emphasizes the practical application of future occupation. As the most widely used language in the world, English seems to be quite important and it is an application subject that needs to accumulate and practice knowledge constantly. In English education of higher vocational colleges, what students learn is not only the foundation of English, but also the integration of social practice to improve their English application ability. Everyone differs in English learning ability as well as their theoretical basis of learning, but in the final analysis, it aims to cultivate the ability to communicate with others, so the ultimate meaning of English education is that it can be applied to social practice.

With the support of Internet big data, the reform of English education in higher vocational colleges has made a great breakthrough. Both teachers' teaching mode and students' application practice have been widely supported by resources. Big data has brought abundant learning resources to students and teachers. At the same time, all kinds of learning tools can be adjusted, to a certain degree, according to students' learning conditions, which greatly strengthens the communication between teachers and students. It is also a positive impetus to the development of traditional teaching mode and learning method.

\section{Present Situation of Public English Teaching in Higher Vocational Colleges}

The development of Internet economy has greatly eliminated the communication barriers between people and big data have greatly affected our life, education, and work by virtue of its characteristics such as fast transmission, large data storage, strong resource integration ability and so on. In the background of globalization, communication between different countries develops faster, and the usage of English is becoming more and more extensive. Talent recruitment puts higher requirement of talents' English ability in recent years. People with strong English ability have more competitive advantages in the fierce recruitment. Therefore, based on this background, the development of English education in Higher Vocational Colleges has gained more attention and support by the government. With the support of Internet big data, the present situation of English teaching has the following points.

\subsection{Promote Individualized Teaching of Students}

With the traditional teaching mode, because of different English practical ability of students, 
comparatively weak basis and restricted learning resources, it is also very limited if they want to improve their English practical ability. With the mutual assistance of Internet big data, we can carry on the individualized education for students. Through big data, it is possible for us to evaluate students' learning ability, analyze their weakness of learning and help to get pertinent improvement. According to students' unique learning interest and learning mode, we should make appropriate learning plans for students and improve their learning efficiency. In this case, it can greatly improve their English learning interest, enhance their English level quickly, and make teachers' teaching more effective, which is a great promotion for students' individualized development and autonomous learning.

\subsection{Abundant Channels of Learning Resources}

Traditional English learning, whether teachers or students, can only access to very limited English resources. The learning channel is single and teaching mode is also quite fixed. However, with the development of Internet big data, information has been spread rapidly, and the channels of people's access to resources become rich and colorful. In addition to the traditional study in colleges, there are also many online learning platforms and online libraries, by which students can learn a great deal of English knowledge through a single computer. Social tools enable them to communicate face-to-face with foreigners in English which was unthinkable before the development of Internet. Abundant English resources also make it easy for teachers to access to teaching materials, thus they are able to obtain more material resources close to social practice, better combine language theories with social practice, change the previous boring teaching mode, and greatly improve students' interest in learning. At the same time, English knowledge is made to be easier to understand, letting teaching concept of teachers keep pace with the times and get continuous improvement.

\subsection{Innovate Teaching Mode Constantly}

Internet big data is characterized by constant innovation and change in response to the needs of social life, which also applies to English teaching. According to the different characteristics of students they teach, teachers can make a variety of designs for teaching programs. By combining big data with the traditional teaching mode, it will be conducive to give full role to students' subjective initiative in learning, constantly stimulate their curiosity and desire for knowledge, enhance the application of theoretical basis learned and greatly improved their English application skills.

\section{Influence on Public English Teaching in Higher Vocational Colleges from Big Data and Change of Teaching}

The development of big data has made a great change in English teaching. Whether in teaching mode, teaching idea, teaching goal, teaching means and so on, the influence of Internet data is very obvious. With the continuous development of Internet technology, English education is being faced with redefinition and reconstruction.

\subsection{Change of Educational Resources and Influence of Big Data}

English teaching is mainly to cultivate students' ability of listening, speaking, reading and writing, and the ultimate goal is to develop their ability to communicate smoothly in English. The traditional teaching mode is mainly based on textbooks and teaching materials. Its teaching and learning mode is single and fixed, but the introduction of big data makes teachers and students be able to access to their desired resources on the Internet any time and anywhere, so it can been seen that big data can remove the obstacles of information dissemination and also accelerate the speed of information exchange. In addition, teachers are capable of getting more vivid and interesting teaching resources, such as audiovisual information, teaching audio materials, and so on. Learning tasks can be arranged through Internet, through which, teachers can quickly analyze students' learning effect and learning ability, and design pertinent teaching mode for students. 
There is also a huge change taken place in teaching mode. In the past, teachers rely on books, but now they also can make use of Internet. In addition to the boring knowledge and words of books previously, now there are also interesting audios, videos, animation and other English materials, which make it possible for students to improve oral practice ability. These huge changes are caused by the tremendous impact of Internet big data. But because of this, students are able to quickly improve their learning ability in a short period of time, keep learning enthusiasm, accumulate English knowledge, transform theoretical basis into their own social practice and improve English application proficiency.

\subsection{Change of Teaching Means and Teaching Tools and Influence of Big Data}

Previous English teaching means and teaching tools are very single, all of which depend on books. But now teaching methods are rich and colorful. We can use projector, mobile phone, computer and other devices to combine pictures, teaching videos and audios, and then apply them into traditional teaching classroom, so that teaching contents are easier to be understood and easily to be absorbed by students. This changed the characteristic of dullness of the past classroom and give full play to teachers' teaching characteristics, so students can obtain the most advanced teaching resources.

\section{Challenge Brought to Public English Teaching from Big Data}

Although Internet big data has greatly promoted English teaching and greatly improved students' English application ability, it has also brought some challenges to English teaching.

\subsection{Challenge of Teachers' Self-orientation}

In the traditional teaching mode, more English learning is dominated by teachers' teaching. Because students can only acquire knowledge through teachers' teaching, so teachers have a great authority in students' mind. But with the development of Internet, students can learn in a variety of ways. Because of rich learning channels, even if students abandon the classroom learning, they can also obtain professional English knowledge from other ways. Therefore, it is a great challenge for teachers to maintain their former authority. Secondly, in the past, teachers only need to use textbooks to teach, but now the rich teaching resources and teaching means make teachers change from a resource provider to a resource integrator. Therefore, they need to learn these new techniques, integrate the best learning plan according to students' different interests, learning ability, etc., learn to use information technology to help students learn English better, and analyze the weakness of students' learning with advanced technology. All of these are teachers' challenges.

Nowadays teachers are more of a pilot and a light for students' learning which play the function of enlightenment. Because of numerous data on the Internet, students have very limited social experience, so teachers always use their own experience to screen the most effective learning resources to cultivate students' ability to think autonomously, stimulate their enthusiasm for learning, and develop innate talents for language learning. The great change of teachers' function is a great challenge brought by the development of English teaching.

\subsection{Challenges of the Usage of Teaching Tools}

A series of teaching tools produced by Internet data have enriched teachers' teaching methods, but only when teachers are familiar with these teaching tools can they exert their great effects. Previous teaching depended on books and social experience was based on oral instruction. But today, Internet tools require teachers to master their core technology and find the most professional and scientific knowledge through them. Combined with students' learning progress and learning situation, teachers should carry out personalized teaching based on various online platforms and online data. Today, teaching does not only refer to written teaching programs, but also the application of big data to optimize their own programs. 


\section{Measures to Improve the Teaching of Public English in the Future}

\subsection{Clear Teaching Ideas}

Although the Internet has a vast amount of teaching resources, students have a lot of access to learning, but sometimes teaching effect is not particularly obvious. It is because that in the teaching process, teachers do not have a clear teaching idea, resulting into various teaching accidents. Teachers should communicate with students as friends in class and maintain an approachable state. It is necessary for them to correct their own mentality, create a harmonious and fair learning environment, communicate more with students, actively understand their inner world and listen to their wishes.

\subsection{Unified Teaching Objectives}

Although big data is abundant, a small part of changes also brings the risk of teaching failure. Students' needs of professional development, learning contents and learning ability must be combined to set up clear learning goals for students and unify teaching goals for teachers, so that students will not lose their own direction in the process of learning. Teachers are required to pay more attention to the practical teaching of English, and at the same time, strengthen the construction of students' theoretical foundation. At the same time, teachers should also stress the development of students except learning, such as personal three views, emotional world, etc., because teaching is to cultivate students be knowledgeable.

\subsection{Innovative Teaching Methods}

Teachers should learn to innovate teaching methods by using big data, not just copy mechanically. They are suggested to also learn to innovate various teaching methods to meet the needs of students, let students participate in interesting activities, stimulate them to think autonomously and participate in their own learning by replacing the rigid teaching mode with interactive teaching mode.

\section{Conclusion}

Internet big data plays an important role in Public English teaching in Higher Vocational Colleges, but it was also accompanied by various challenges, so in the process of concrete implementation, there will be some problems. We must maintain this correct development direction and unceasingly consummates teaching patterns.

\section{References}

[1] Chen Qingbin. Reconstruction of Teaching Mode of College English Writing in Big Data Era [J]. Foreign language Journal, 2016-05-05.

[2] Zhang Jingyu. Influence of Big Data on English Teaching: The Application of Big Data in English Teaching [J]. Contemporary Teacher Education, 2016-03-15.

[3] Yang Yanlong. Innovation and Information Reform of College English Teaching Mode in Big Data Era [J]. Computer-assisted Foreign Language Education, 2017-08-20. 